\title{
Phytomanagement: perspectives of using of phytoremediation technology in Kazakhstan
}

\author{
Saule Atabayeva ${ }^{1, *}$, Saule Kenzhebayeva ${ }^{1}$, Ravilya Alybayeva ${ }^{1}$, Saltanatm Asrandina ${ }^{1}$, \\ Sabina Shoinbekova ${ }^{1}$ \\ ${ }^{1}$ Al-Farabi Kazakh National University, al-Farabi Ave. 71, 050040 Almaty, Kazakhstan
}

\begin{abstract}
The content of heavy metals around the metallurgical plants of East Kazakhstan in the soil and plants growing around these plants was studied. It was determined the concentration of heavy metals in soils, plant organs, it was calculated bioconcentration factor and the level of extraction of heavy metals by sunflower and lawn grasses. The study of sunflower plants and lawn grasses showed that the studied species accumulated a significant amount of heavy metals mainly in the roots. Sunflower plants and lawn grasses had high accumulation activity and accumulated a significant amount of heavy metals in their organs. Determination of the content of heavy metals in the soil showed a significant removal of heavy metals from the soil, which indicates a high degree of phytoextraction of heavy metals by the studied plant species.
\end{abstract}

\section{Introduction}

Toxic technogenic danger poses a great threat to humanity, and this threat is growing continuously. Kazakhstan, which is one of the ten largest countries of the world community, is currently considered ecologically vulnerable in all respects. One of the problems of modern ecology is the pollution of ecosystems with heavy metals. The East Kazakhstan region is an industrial center in which a number of strategic objects of the chemical industry, mechanical engineering, and others are concentrated. Powerful enterprises of the mining and metallurgical industries and the largest non-ferrous and rare metal plants are operating here. The territory of the East Kazakhstan region is experiencing a powerful anthropogenic load; about one billion tons of solid waste has accumulated in various storage facilities. About 100 pollutants are registered in the air, water and soil of the region. Constantly growing volumes of industrial waste form new technogenic landscapes. They become sources of intense dust generation and spread over hundreds of kilometers, polluting the environment and posing a threat to the health of the population and the biodiversity of the region [1]. Heavy metals entering the atmosphere with industrial emissions and, accordingly, into the soil actively affect the vegetation and the ecosystem as a whole. The soils of the East Kazakhstan region are most polluted with $\mathrm{Zn}, \mathrm{Cd}, \mathrm{Pb}, \mathrm{Cu}$ as a result of long-term activity of metallurgical plants in Zyryanovsk, Ridder and Ust-Kamenogorsk [2].

*Corresponding author: sauleat@yandex.ru 
Heavy metals are pollution of anthropogenic origin, which are characterized by high toxicity, mutagenic and carcinogenic effects. An important feature of heavy metals is that they belong to the class of non-specific substances that are normally present in the biosphere, in contrast to specific pollutants like pesticides. Another difference from other pollutants for heavy metals, in principle, the concept of "self-cleaning" does not apply. As a result of all the processes of migration and their dispersion, an irreversible increase in concentration occurs in water, soil, air, food, i.e. pollution of natural environments and biota occurs [2].

Near industrial enterprises, instead of natural phytocenoses, a modern "technogenic flora" appears which can grow without visible toxicity symptoms on contaminated soil [3] the property of plants to transfer large concentrations of heavy metals in the soil and accumulate them in their organs has been widely used recently to clean contaminated soils. Phytoremediation involves the use of plants to clean the environment as an alternative to engineering technology. Phytoremediation is defined as the technology of using plants to clean contaminated soils, being economically viable and safe compared to other physicochemical methods of purification [4].

Phytoremediation technology includes phytoextraction (using plants to extract metals from the soil), phytovolysis (using plants to volatilize chemical elements), rhizofiltration (using plant roots to extract metals from running water) and phytostabilization (using plants to transfer metals into less toxic forms, but without removing them from the soil) [5]. For phytoextraction of heavy metals from the soil, the use of heavy meta-hyperaccumulators is most beneficial.

The term "hyperaccumulator" refers to plant species that accumulate 10-100 times more metals than ordinary plants. These plants can be used to extract toxicants from the soil and thus can help restore fertility to contaminated lands. Hyperaccumulators are endemic to those soils that are contaminated with heavy metals and do not compete with other species on uncontaminated soils. The accumulation of metals by plants in non-toxic form is one of the strategies used by plants to survive in conditions of severe environmental pollution [6].

The technology of phytoextraction of heavy metals from the soil suggests, "Refers to plant species that accumulate 10-100 times more metals than ordinary plants (Table 3). Hyperaccumulators cause considerable interest from the point of phytoremediation [7], phytobuilding [8] and biofortification (improvement) of agricultural crops [9, 10]. Hyperaccumulators are used to extract toxicants from the soil, thus reducing their content in the soil, which also contributes to the restoration of fertility of polluted lands.

Hyperaccumulators are endemic to soils that are contaminated with heavy metals and do not compete with other species on uncontaminated soils. These plants were found in mines, tailings, serpentines. R. Brooks (1998)[11] defined hyperaccumulative plants, which are currently used by all researchers in this field. Heavy accumulators are called hyperaccumulators, which accumulate 10-100 times more metals than ordinary plants mainly in aboveground organs. The hyperaccumulators of certain metals include plant species that accumulate metals above a certain concentration threshold. For example, hyperaccumulators are plants that accumulate zinc $(\mathrm{Zn})>10,000$, lead $(\mathrm{Pb})>1000$, cadmium $(\mathrm{Cd})>100 \mu \mathrm{g} / \mathrm{g}$ in the aboveground organs.

For the effective development of phytoremediation, each element should be considered separately. An agronomic approach is necessary taking into account the physicochemical properties of metal, soil, and the genetic properties of plants [12].

Phytomanagement $[1-3,14]$ describes the manipulation of soil-plant systems to control the flow of pollutants in the environment. The goal of phytocontrol can be to eliminate the deficiencies in the main trace elements, such as $\mathrm{Zn}$, in cultivated crops and to reduce environmental risks associated with increased concentrations of these elements in the soil. An important component of phytomanagement is that it must either be cheaper than other recovery technologies, or be profitable, producing valuable plant biomass products. 
Phytomanagement - a complex phytoremediation methods without the difference between the processes involved.

For phytoremediation technology can be used plants-hyperaccumulators, which are endemic to soils that are contaminated with heavy metals and do not compete with other species on uncontaminated soils. Accumulation of metals by plants in non-toxic form is one of the strategies used by plants to survive in conditions of severe environmental pollution. The most well-known heavy metal hyperaccumulators include: Ambrosia artemisiifolia L. (ragweed ragweed), Thlaspi rotundufolium L., Thlaspi caerulescens L. (yarok), which absorb a significant amount of $\mathrm{Zn}, \mathrm{Cd}, \mathrm{Pb}$. Alyssum L. and Arabidopsis L. belong to $\mathrm{Ni}$ hyperaccumulators [11].

Phytoextraction is quite long in terms of the duration of technological phytoremediation. Therefore, for the productive use of contaminated areas, it is necessary to use an economically viable and socially acceptable method of cleaning up contaminated lands. Industrial crops, "energy crops" with phytoextraction potential may be candidates for biofuel production [15]. The use of oils seeds plants as phytoremedants will reduce the level of pollution on the one hand, and on the other hand, increase the productive value of contaminated soils. The most suitable plant species are sunflower plants (Helianthus annus L.), castor oil plants (Ricinus communis L.), and white mustard (Sinapis Alba L.).

Helianthus annuus L. have a good potential to extract large amounts of trace metals due to accumulation of high biomass by the aboveground parts, if a sufficient concentration of them in the tissues is achieved. However, the low bioavailability of metals limits the process of their translocation to aboveground organs. The addition of EDTA or citric acid increased the concentration of heavy metals in plant tissues. At the same time, the concentration in tissues increased and the removal of heavy metals by plant biomass increased [16].

Thus, bioremediation of contaminated soils and surface waters is the most promising and less expensive way of phytomanagement, the cheap way to clean the environment from pollution.

In this regard, the aim of this work was to study the metal-accumulative ability of sunflower plants grown in the field on the territory of the Zinc Plant in Ridder and the Metallurgical Factory in Ust-Kamenogorsk.

\section{Materials and methods}

The objects of research were the territories of the main sources of environmental pollution by heavy metals - The Zinc Plant in Ridder city and the metallurgical factory KazZinc JSC in Ust-Kamenogorsk (UMF) of Eastern Kazakhstan By agreement with the environmental service of these enterprises, experiments on testing phytoremediation regulations were laid in the territory of these plants. The administration of the plants allocated $100 \mathrm{~m}^{2}$ plot on the territory of the Zinc Plant in Ridder city and $65 \mathrm{~m}^{2}$ on the territory of the UMF. The plots were cultivated and divided into 10 small plots of $2 \times 4 \mathrm{~m}$ each in Ridder city, and in UstKamenogorsk - into two plots of 15 and $50 \mathrm{~m}^{2}$.

On the territory of the metallurgical plant, a mixture of seeds of wild species of cereal plants (Poa pratensis, Festuca rubra, Arrhenatherum elatius) and sunflower seeds (Helianthus annuus) was seeded. Plots without plants were used as control.

Quantitative determination of heavy metals was carried out by atomic absorption method with flame atomization: LMN / SOP-08 "Workflow of Analyzer-300 Perkin Elmer (in flame) $[17,18]$.

The content of heavy metals in certain organs of the grass mixture - lawn grass species of cereal plants (Poa pratensis, Festuca rubra, Arrhenatherum elatius) and sunflower (Helianthus annuus) planted in these areas was determined.

Measurement of biometric indicators was carried out according to generally accepted 
methods. Plants were divided into aerial parts and roots. To determine the dry biomass, the plant parts were placed in an drying box and dried at $\mathrm{t}-105^{\circ} \mathrm{C}$ to constant weight, cooled to room temperature and weighed.

Bioconcentration factor $(\mathrm{BCF})$ was calculated according to the following formula: $\mathrm{BCF}$ $=\mathrm{C}$ plant $/ \mathrm{Csoil}$, where $\mathrm{C}$ plant and Csoil - concentrations of heavy metals in plant organs and soil, respectively [19].

\section{Results and discussion}

Estimation of contamination level of soils on the territory of Zinc Plant. The soils around the Ridder Zinc Plant are heavily contaminated with heavy metals: cadmium, zinc, lead and copper. The predominant soil pollution is observed in the southern and northern directions, which is associated with a wind rose (Table 1).

Table 1. Content of heavy metals in soils around Zinc Plant.

\begin{tabular}{|c|c|c|c|c|c|c|c|c|c|c|c|c|}
\hline \multirow{2}{*}{$\frac{n}{\frac{\pi}{\pi}}$} & \multicolumn{2}{|c|}{$\begin{array}{l}\text { Control } \\
\mathrm{ABG}^{*}\end{array}$} & \multicolumn{2}{|c|}{$\begin{array}{l}\text { Territory of } \\
\text { Zinc Plant } \\
\text { (Center) }\end{array}$} & \multicolumn{2}{|c|}{$\begin{array}{c}\text { South } \\
(\sim 500 \mathrm{~m})\end{array}$} & \multicolumn{2}{|c|}{$\begin{array}{c}\text { North } \\
(\sim 500 \mathrm{~m})\end{array}$} & \multicolumn{2}{|c|}{$\begin{array}{c}\text { East } \\
(\sim 500 \mathrm{~m})\end{array}$} & \multicolumn{2}{|c|}{$\begin{array}{c}\text { West } \\
(\sim 500 \mathrm{~m})\end{array}$} \\
\hline & $\begin{array}{c}\mathrm{mg} / \\
\mathrm{kg}\end{array}$ & $\begin{array}{c}\text { MPC } \\
* *\end{array}$ & $\mathrm{mg} / \mathrm{kg}$ & $\underset{* *}{>\mathrm{MPC}}$ & $\mathrm{mg} / \mathrm{kg}$ & $\begin{array}{c}>\mathrm{MPC} \\
* *\end{array}$ & $\mathrm{mg} / \mathrm{kg}$ & $\underset{* *}{>\text { MPC }}$ & $\mathrm{mg} / \mathrm{kg}$ & $>\underset{* *}{>\mathrm{MPC}}$ & $\mathrm{mg} / \mathrm{kg}$ & $\begin{array}{l}\text { MP } \\
\mathrm{C}^{* *}\end{array}$ \\
\hline $\mathrm{Cd}$ & 1.6 & 3.2 & 83.5 & 167.0 & 539.1 & 1078.0 & 120.0 & 240.0 & 9.3 & 18.6 & 11.3 & 22.6 \\
\hline $\mathrm{Pb}$ & 27.4 & 4.5 & 932.8 & 155.0 & 5990.4 & 998.0 & 1645.0 & 274.0 & 195.8 & 32.0 & 12.3 & 2.0 \\
\hline $\mathrm{Cu}$ & 17.9 & 6.0 & 645.7 & 215.0 & 5616.0 & 1872.0 & 1749.0 & 583.0 & 373.8 & 124.0 & 43.2 & 14.0 \\
\hline $\mathrm{Zn}$ & 99,9 & 4.0 & 177820.0 & 773 & 129792.0 & 5643.0 & 22991.0 & 100.0 & 2898.0 & 126.0 & 355.7 & 15.0 \\
\hline & & & & & & $\mathrm{Kg}$ & & & & & 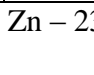 & \\
\hline
\end{tabular}

As can be seen from the Table 1, the content of heavy metals in soils is tens, hundreds or more times higher than the maximum permissible concentration (MPC). It should be noted that the soils of the Altai Botanical Garden, which we adopted as a control background, also differed in the high content of heavy metals. Here, the excess of MPC for cadmium was 3.2; for copper - 6 , for lead - 4.5 and for zinc - 4 times. The soils of the territories of the zinc plant itself contained significantly higher amounts of heavy metals. Therefore, for example, the excess of the MPC for cadmium is - 1078, for zinc - 773, for copper - 215 and for lead - 155 times.

Thus, it was found that the territory of the Zinc Plant is contaminated with cadmium, zinc, copper and lead. Concentrations of heavy metals exceed MPC by hundreds times.

Growth and accumulation of biomass by plants under heavy metal pollution. Observations showed that the sown sunflower seeds sprouted amicably on the contaminated soils of the Zinc Plant in Ridder city and the UMF in Ust-Kamenogorsk city. Data on the accumulation of biomass and its distribution among individual organs of sunflower and herbaceous cereal plants are presented in tables 2 and 3. The table 2 shows that the studied wild species of cereal plants grew more intensively and developed on the territory of the Zinc Plant, and sunflower on the territory of the UMF.

The distribution of biomass by organs was significantly different in plants grown under different environmental conditions. Despite the fact that the sowing of seeds was carried out at the same time, the plants at the Zinc Plant in Ridder were lagging behind in development from plants from the UMF in Ust-Kamenogorsk.

Table 2. Total biomass of plants grown in the territory of the zinc plant, $\mathrm{g} / \mathrm{m}^{2}$. 


\begin{tabular}{l|c|c}
\hline \multicolumn{1}{c|}{ Plant species } & Zinc Plant (Ridder) & UMF (Ust-Kamenogorsk) \\
\hline A mixture of lawn grasses & $138.8 \pm 5.1$ & $12.7 \pm 0.6$ \\
\hline Sunflower & $33.43 \pm 1.2$ & $51.8 \pm 2.1$ \\
\hline
\end{tabular}

By the time of harvesting, the plants in Ridder were in the phase - the end of floweringbeginning of the filling phase, while in Ust-Kamenogorsk the plants were completely bloomed and were in the stage of seed formation. The proportion of stems is much lower in Ust-Kamenogorsk compared to Ridder, because the outflow of nutrient substances (photosynthesis products) in plants around UMF is at the completion stage, and in plants around Zinc Plant this process is just beginning. This is evidenced by the data on the distribution of bio-mass among plant organs (Table 3).

Table 3. The distribution of biomass by the organs of sunflower, grown under heavy metals contaminated conditions, $\%$.

\begin{tabular}{l|c|c|c|c|c|c}
\hline \multicolumn{1}{c|}{ Place } & Basket & Top leaves & Lower leaves & Stem & Roots & Whole plant \\
\hline Zinc Plant & 15.2 & 19.6 & 9.6 & 45.8 & 9.8 & 100 \\
\hline UMF & 39.8 & 17.2 & 28.2 & 9.5 & 5.3 & 100 \\
\hline
\end{tabular}

Accumulation of heavy metals in the vegetative organs of plants grown in the zones of action of metallurgical plants in East Kazakhstan. The content of heavy metals in plants grown in the field conditions on the territory of the Zinc Plant in Ridder and in UstKamenogorsk on the territory of UMF was determined. The content of heavy metals in the organs of sunflower in the territory of the Zinc Plant (Ridder city) decreased in the following order (mg/kg): $\mathrm{Cu}-$ lower leaves $\geq$ leaves of the upper tier $>$ stem $>$ roots $>$ basket; $\mathrm{Zn}-$ lower leaves > leaves of the upper tier > basket > stem > roots; Cd - lower leaves o $(117.7 \pm$ $44.76)>$ leaves of the upper tier $(90.14 \pm 2.86)>$ basket $(28.0 \pm 0.82)>\operatorname{stem}(14.3 \pm 0.53)>$ roots $(10.43 \pm 0.41)$; $\mathrm{Pb}$ - leaves of the lower tier > leaves of the upper tier> basket $>$ roots $>$ stem.

Heavy metals are most found in the aboveground organs, indicating strong atmospheric pollution. Zinc in the organs of plants accumulated to the greatest amount in comparison with other metals: $\mathrm{Zn}>\mathrm{Pb}>\mathrm{Cu}>\mathrm{Cd}$. The zinc content was an order of magnitude higher than copper and lead, and almost two orders of magnitude higher than cadmium. In lawn grasses, the content of heavy metals was determined only in aboveground organs. The metal content in the area of the zinc plant decreased in the following order $(\mathrm{mg} / \mathrm{kg}): \mathrm{Zn}(4086.92 \pm 5.9)>$ $\mathrm{Pb}(282.90 \pm 0.9)>\mathrm{Cu}(139.95 \pm 4.6)>\mathrm{Cd}(36.28 \pm 1.7)$ (Table 4). The content of heavy metals in the aerial organs of lawn grasses decreased in the following order $(\mathrm{mg} / \mathrm{kg}): \mathrm{Zn}$ $(3031.36 \pm 1.2)>\mathrm{Pb}(2748.70 \pm 9.3)>\mathrm{Cu}(775.87 \pm 22.3)>\mathrm{Cd}(87.10 \pm 2.5)$ (Table 4)

Table 4. The content of heavy metals in the aboveground organs of lawn grasses, grown on the territories of the Zinc Plant and UMF.

\begin{tabular}{l|c|c|c|c}
\hline \multirow{2}{*}{ Place } & \multicolumn{4}{|c}{ Content of heavy metals, $\mathrm{mg} / \mathrm{kg}$} \\
\cline { 2 - 5 } & $\mathrm{Cu}$ & $\mathrm{Zn}$ & $\mathrm{Cd}$ & $\mathrm{Pb}$ \\
\hline Zinc Plant & $139.95 \pm 4.6$ & $4086.92 \pm 5.9$ & $36.28 \pm 1.7$ & $282.90 \pm 0.9$ \\
\hline UMF & $775.87 \pm 22.3$ & $3031.36 \pm 1.2$ & $87.10 \pm 2.5$ & $2748.70 \pm 9.3$ \\
\hline
\end{tabular}

The content of heavy metals in the organs of sunflower, grown on the territory of UMF, decreased in the following order $(\mathrm{mg} / \mathrm{kg})$ (Table 5):

$\mathrm{Cu}$ - leaves of the lower tier $(1616.78) \geq$ leaves of the upper tier $(1122.60)>\operatorname{roots}(277.47)$ $>$ basket (189.04) > stem $(63,05)$; 
$\mathrm{Zn}$ - leaves of the lower tier (6483.85) > leaves of the upper tier (4193.29) > roots $(1913.92)>$ stem $(709.43)>$ basket $(579,19)$;

$\mathrm{Pb}$ - leaves of the lower tier $(156.26)>$ leaves of the upper tier $(111.12)>\operatorname{roots}(66.24)>$ basket (18.87) $\geq$ stem (18.39);

Cd - leaves of the lower tier (5267.82) > leaves of the upper tier (3603.24) > roots (945.56) $>$ basket $(532.26)>$ stem $(298,66)$.

Table 5. The content of heavy metals in the aboveground organs of sunflower plants (UMF).

\begin{tabular}{l|c|c|c|c}
\hline \multirow{2}{*}{ Plant parts } & \multicolumn{4}{|c}{ Content of heavy metals, $\mathrm{mg} / \mathrm{kg}$} \\
\cline { 2 - 5 } & $\mathrm{Cu}$ & $\mathrm{Zn}$ & $\mathrm{Cd}$ & $\mathrm{Pb}$ \\
\hline Leaves of the upper tier & $1122.60 \pm 42.4$ & $4193.29 \pm 33.0$ & $111.12 \pm 3.3$ & $3603.24 \pm 1.8$ \\
\hline Leaves of the upper tier & $1616.78 \pm 31.1$ & $6483.85 \pm 51.8$ & $156.26 \pm 5.2$ & $5267.82 \pm 27.8$ \\
\hline Basket & $189.04 \pm 5.8$ & $579.19 \pm 21.9$ & $18.87 \pm 0.5$ & $532.26 \pm 18.9$ \\
\hline Stem & $63.05 \pm 2.9$ & $709.43 \pm 58.4$. & $18.39 \pm 0.33$ & $298.66 \pm 7.3$ \\
\hline Roots & $277.47 \pm 9.3$ & $1913.92 \pm 41.2$ & $66.24 \pm 2.2$ & $945.56 \pm 2.9$ \\
\hline
\end{tabular}

Unlike plants grown in the city of Ridder, the content of copper and lead in UstKamenogorsk was an order of magnitude higher, which indicates a strong atmospheric air pollution by these metals. A high content of $\mathrm{Zn}$ in sunflower roots was noted, which is a consequence of significant soil contamination with zinc (Table 5).

Thus, plants growing in a contaminated area have a high accumulative ability.

Determination of bioaccumulation coefficient of lawn plant species and sunflower plants. To assess the degree of bioaccumulation of heavy metals by the organs of the studied plants, the bioconcentration factor was calculated. The study of this indicator in the aerial organs of lawn grasses revealed that for all metals it is higher than 1 . If we compare different areas, the greatest value of the bioconcentration factor was observed mainly around the Zinc Plant. Among metals, the highest value of this indicator was found for cadmium, and for other metals the differences between themselves were not so great. According to this indicator, in the region of the Zinc Plant (Ridder city), metals can be arranged in the following row: $\mathrm{Cd}>$ $\mathrm{Zn}>\mathrm{Pb}>\mathrm{Cu}$, in the region of $\mathrm{UMK}-\mathrm{Cd}>\mathrm{Cu}>\mathrm{Pb}>\mathrm{Zn}$ (Figure 1).

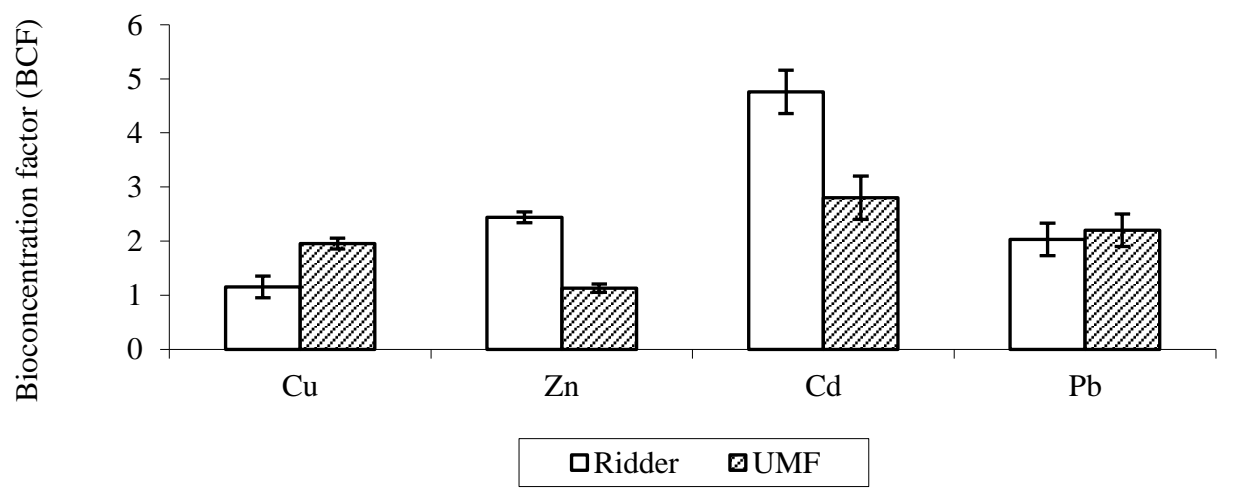

Fig. 1. Bioconcentration factor for aboveground organs of lawn plant species in the area of the Zinc Plant (Ridder city) and the UMF.

For aboveground organs of sunflower, the bioconcentration factor was also greatest in the area of the Zinc Plant (Ridder city) for cadmium, and the smallest for lead. In the UMF area, the highest value of this indicator was observed for copper, the smallest - for zinc. 
The bioconcentration factor for aboveground organs of sunflower in the area of the Zinc Plant decreased in the following order: $\mathrm{Cd}>\mathrm{Zn}>\mathrm{Cu}>\mathrm{Pb}$, in the region of $\mathrm{UMF}-\mathrm{Cu}>\mathrm{Cd}$ $>\mathrm{Pb}>\mathrm{Zn}$ (Figure 2).

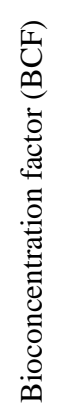
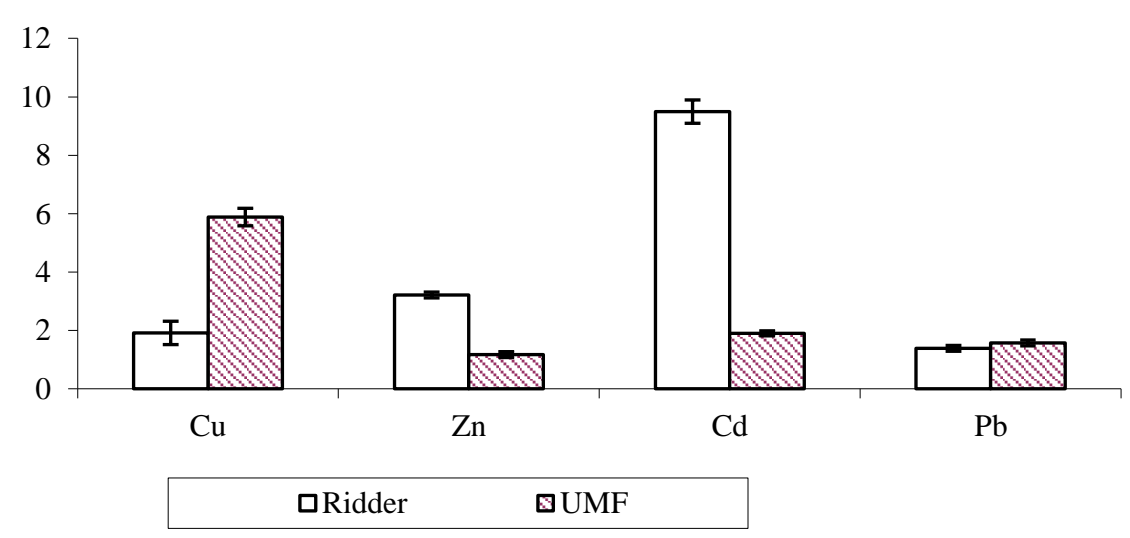

Fig. 2. Bioconcentration factor for aboveground organs of sunflower plants in the area of the Zinc Plant (Ridder city) and the UMF.

For sunflower roots, the bioconcentration factor was of greatest importance for cadmium in the area of the zinc plant and in the region of UMF, its least value was observed for lead. The decrease in the bioconcentration factor for sunflower roots in the area of the Zinc Plant and UMF can be represented as follows: $\mathrm{Cd}>\mathrm{Zn}>\mathrm{Cu}(\mathrm{Pb})>\mathrm{Pb}(\mathrm{Cu})$ (Figure 3).

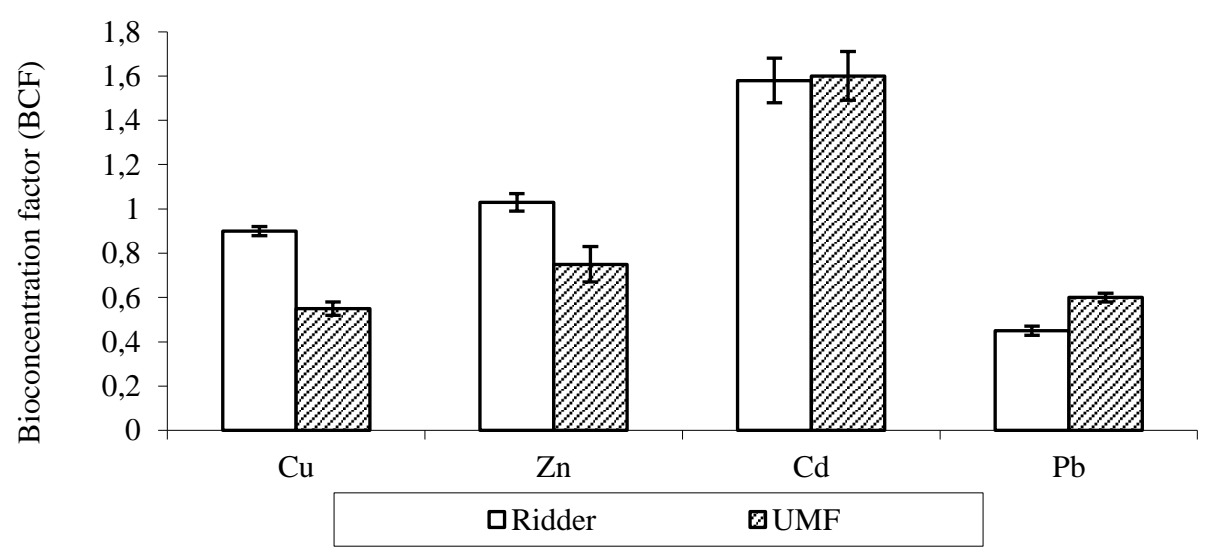

Fig. 3. Bioconcentration factor for sunflower roots in the area of the Zinc Plant (Ridder city) and the $\mathrm{UMF}$.

For the roots of sunflower, the value of the bioconcentration factor in absolute value was almost an order of magnitude lower than for the aboveground organs: for copper - 2 times, zinc and lead - 3 times, cadmium - 6 times. The high concentration of heavy metals in the aboveground organs is caused mainly by a high degree of atmospheric pollution, and is not the result of translocation of heavy metals from the roots to the aboveground organs. 
Thus, it was found that sunflower plants and species of lawn plants accumulate a significant amount of heavy metals in their organs. This is evidenced by the high value (more than 1) of the bioconcentration factor of heavy metals for aboveground organs and roots.

Since the studied plant species are not hyperaccumulators as defined by R. Brooks [11], it should be assumed that a significant accumulation of heavy metals in the aboveground organs of plants indicates the result of a strong atmospheric pollution. However, these species accumulating metals in the roots contribute to their absorption from the soil, and also accumulating them in the aboveground organs also contribute to reducing environmental pollution by heavy metals.

The percentage of heavy metals in plant organs is an integral indicator in the selection of plants for phytoremediation. In the area of the zinc plant, the largest percentage of zinc was found in the roots and aboveground organs of lawn grasses $(0.8$ and $0.9 \%)$, and in the region of the metallurgic factory in Ust-Kamenogorsk, the largest percentage of lead was found in the aboveground organs of sunflower $(0.9 \%)$ and in the aerial organs of lawn grasses, the zinc content was equal to $0.9 \%$.

Table 6. The percentage of heavy metals in plant samples.

\begin{tabular}{l|c|c|c|c}
\hline \multicolumn{1}{c|}{ Plant parts } & $\begin{array}{c}\text { Cu, \% dry } \\
\text { weight }\end{array}$ & $\begin{array}{c}\text { Pb, \% dry } \\
\text { weight }\end{array}$ & $\begin{array}{c}\text { Cd, \% dry } \\
\text { weight }\end{array}$ & Zn, dry weight \\
\hline \multicolumn{5}{c}{ Ridder, KazZinc. } \\
\hline \multicolumn{5}{c}{ Sunflower } \\
\hline Aboveground part & 0.01 & 0.2 & 0.01 & 0.5 \\
\hline Roots & 0.001 & 0.01 & 0.001 & 0.1 \\
\hline \multicolumn{5}{|c|}{ Lawn grass } \\
\hline Aboveground part & 0.1 & 0.2 & 0.02 & 0.8 \\
\hline Roots & 0.09 & 0.2 & 0.04 & 0.9 \\
\hline \multicolumn{5}{|c}{ Sunflower } \\
\hline Aboveground part & 0.31 & 0.9 & 0,06 & 0,5 \\
\hline Roots & 0.02 & 0.13 & 0,01 & 0,1 \\
\hline \multicolumn{5}{|c}{ Lawn grass } \\
\hline Aboveground part & 0.15 & 0.11 & 0.03 & 0,9 \\
\hline Roots & 0.02 & 0.07 & 0.007 & 0.03 \\
\hline
\end{tabular}

Thus, the concentration of metals in the aboveground organs of plants was higher in aboveground organs than in the roots. The translocation coefficient of metals from roots to aboveground organs was higher than 1. Obviously, this indicator is not a natural phenomenon, and is the result of a severe atmospheric pollution.

Determination of the residual content of heavy metals in the soil after phytoremediation proccess. The determination of the residual content of heavy metals in the soil was determined after planting a mixture of seeds of wild species of cereal plants (Poa pratensis, Festuca rubra, Arrhenatherum elatius) and sunflower seeds (Helianthus annuus) after 1, 2 and 3 months.

The content of heavy metals in the rhizosphere of the soil is steadily decreasing over 3 months (Figures 4, 5). In the area of the KazZinc plant (Ridder city), the content of copper and zinc under sunflower plants decreased to the greatest extent. For example, in the area of a zinc plant in the soil under sunflower plants, the copper content halved in a month, and after 3 months - by $76.5 \%$; zinc content decreased by 51 and $58 \%$ after 2 and 3 months, respectively. The cadmium and lead content decreased to a lesser extent: the lead content decreased by 13 and 67\%, cadmium - 29 and 67\%, respectively, after 2 and 3 months. 


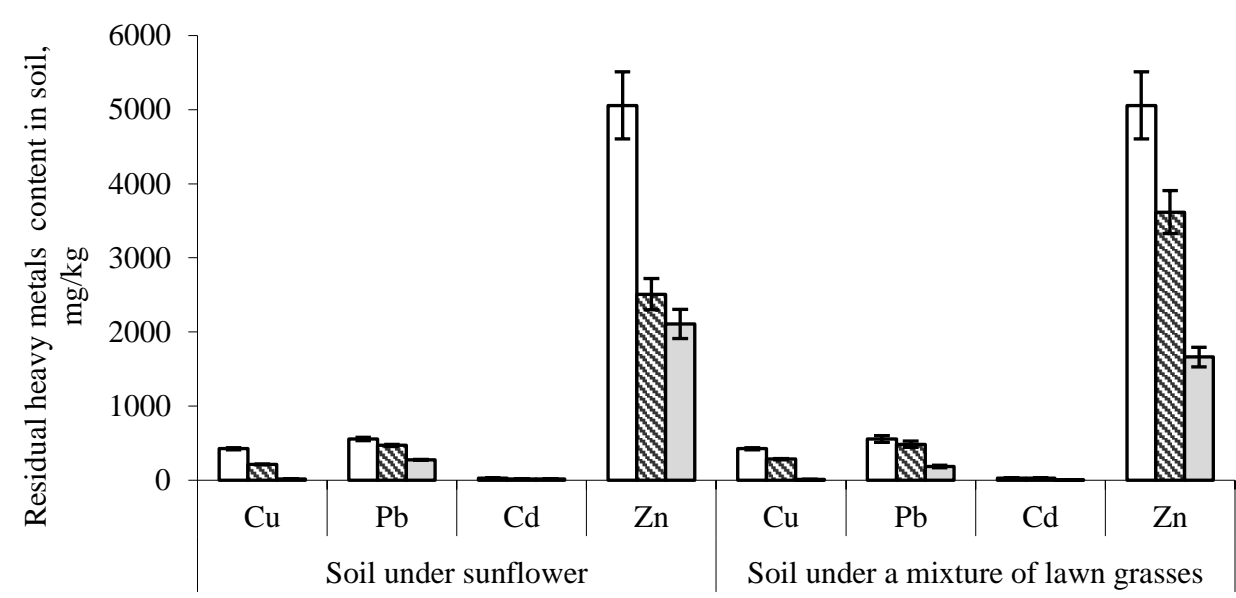

口After 1 month $\mathbf{Q}$ After 2 month $\mathbf{\square A f t e r} 3$ month

Fig. 4. The content of heavy metals in the soil, Ridder, Zinc Plant.

Under a mixture of lawn grasses, the metal content decreased as follows: copper - by 30 and $98 \%$, lead - by 13 and $67 \%$, cadmium - by 7 and 75\%, zinc - by 29 and $67 \%$, after 2 and 3 months, respectively.

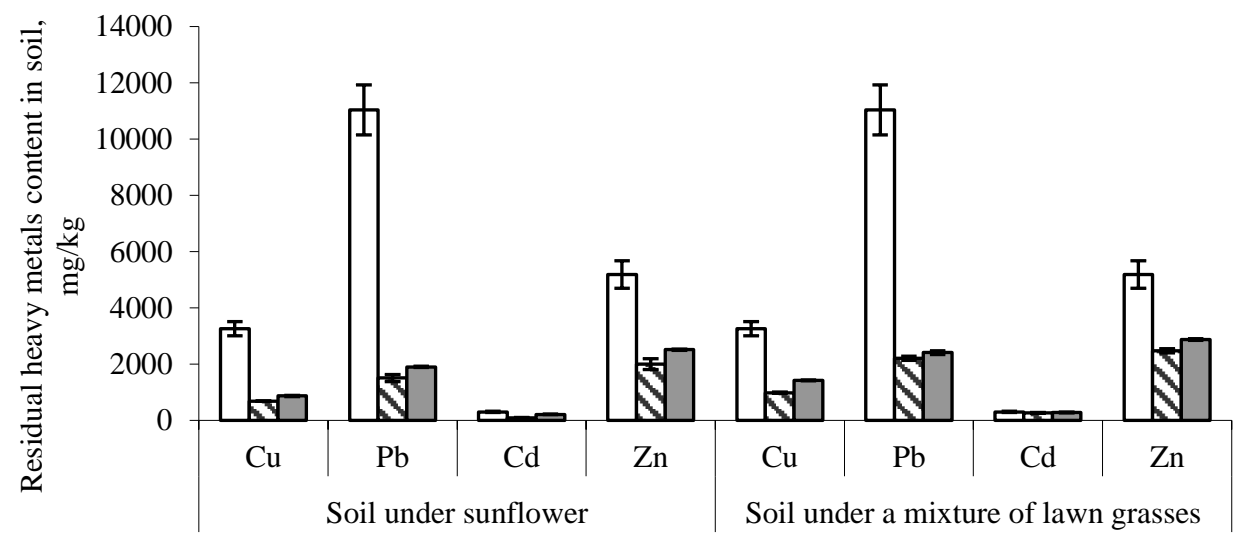

DAfter 1 month $\mathbf{Q}$ After 2 month $\quad$ After 3 month

Fig. 5. The content of heavy metals in the soil, UMF, Ust-Kamenogorsk.

When comparing the phytoextraction ability of sunflower and a mixture of lawn grasses, the residual metal content in the soil under these crops did not differ much.

In the area of the metallurgical plant in Ust-Kamenogorsk, a different picture was observed. In general, in this region the degree of decrease in the content of heavy metals is higher than in Ridder city. The degree of phytoextraction in the variant with sunflower was higher to the greatest extent for copper and lead compared to other elements: for copper, the reduction was 79 and $73 \%$, for lead - 86 and $83 \%$ after 2 and 3 months, respectively. These 
indicators for cadmium were 69 and $61 \%$, for zinc - 61 and 52\%, after 2 and 3 months, respectively (Table 7).

Table 7. The residual content of heavy metals in the soil on the territories of KazZinc (Ridder) and UMF (Ust-Kamenogorsk).

\begin{tabular}{|c|c|c|c|c|}
\hline & $\mathrm{Cu}$ & $\mathrm{Pb}$ & $\mathrm{Cd}$ & $\mathrm{Zn}$ \\
\hline Terms & $\%$ & $\%$ & $\%$ & $\%$ \\
\hline \multicolumn{5}{|c|}{ KazZinc (Ridder) } \\
\hline \multicolumn{5}{|c|}{ Sunflower } \\
\hline 1 month & 100 & 100 & 100 & 100 \\
\hline 2 months & 50 & 84 & 60 & 49 \\
\hline 3 months & 3,5 & 49 & 63 & 42 \\
\hline \multicolumn{5}{|c|}{ Lawn grasses } \\
\hline 1 month & 100 & 100 & 100 & 100 \\
\hline 2 months & 70 & 87 & 93 & 71 \\
\hline 3 months & 2 & 33 & 25 & 33 \\
\hline \multicolumn{5}{|c|}{ UMF, Ust-Kamenogorsk } \\
\hline \multicolumn{5}{|c|}{ Sunflower } \\
\hline 1 month & 100 & 100 & 100 & 100 \\
\hline 2 months & 21 & 14 & 31 & 39 \\
\hline 3 months & 27 & 17 & 39 & 48 \\
\hline \multicolumn{5}{|c|}{ Lawn grasses } \\
\hline 1 month & 100 & 100 & 100 & 100 \\
\hline 2 months & 30 & 20 & 86 & 48 \\
\hline 3 months & 43 & 22 & 92 & 55 \\
\hline
\end{tabular}

Under a mixture of lawn grasses, the content of heavy metals decreased as follows: copper - by 70 and $57 \%$, lead - by 80 and $78 \%$, cadmium - by 14 and $8 \%$, zinc - by 52 and $45 \%$ after 2 and 3 months, respectively.

Thus, it was found that in the rhizosphere of planted sunflower plants and a mixture of lawn grasses, the content of heavy metals steadily decreased over 3 months. It was not possible to establish a clear pattern in the degree of phytoextraction separately for each metal and plant species. This is probably due to the different mineral composition of soils, the degree of acidity, which are of no small importance in the absorption of metals by plants, as well as the different degrees of atmospheric pollution with one or another metal in the area of the KazZink plant in Ridder and in Ust-Kamenogorsk, which also contributes to the content of metals in the soil.

Therefore, we can conclude that sunflower plants and a mixture of lawn grasses make approximately the same contribution to the processes of phyto-purification of soils from heavy metals.

Sunflower plants and wild species of cereal plants had high accumulation activity and accumulated a significant amount of heavy metals in their organs. Determination of the content of heavy metals in the soil showed a significant removal of heavy metals from the soil, which indicates a high degree of phytoextraction of heavy metals by the studied plant species.

Thus, the soils of the territory of metallurgical plants of the East Kazakhstan region are significantly contaminated with heavy metals, exceeding the MPC by tens and hundreds of times. 


\section{Conclusion}

Testing a mixture of lawn grasses and sunflower plants in the area of the Zinc Plant in Ridder and the Metallurgical Plant in Ust-Kamenogorsk showed that they have a remediation ability.

When comparing sunflower plants and a mixture of lawn grasses with each other in the region of Ridder and UMF, it was found that the total aboveground mass of sunflower far exceeded the biomass of lawn grasses and wheat grass creeping. This indicates the possibility of the greatest removal of heavy metals due to the accumulation of significant biomass compared with cereal species.

A study of the content of heavy metals in plant organs showed that copper and cadmium accumulated to the least extent, and lead and zinc to the greatest extent. The concentration of metals in the aboveground organs of lawn grasses had the same pattern. Zinc and lead ions were most accumulated.

The comparison of the concentration of heavy metals in the organs of sunflower and lawn grasses, the metal content in the organs of lawn grasses exceeded the concentration in sunflower. In sunflower plants, a high degree of phytoextraction is achieved mainly due to plant biomass.

The concentration of metals in the aboveground organs in all studied species was higher than in the roots, probably due to strong atmospheric pollution.

The percentage of heavy metals in plant organs is an integral indicator in the selection of plants for phytoremediation. In the area of the zinc plant, the largest percentage of zinc was found in the roots and aboveground organs of lawn grasses (0.8 and 0.9\%), and in the region of UMF in Ust-Kamenogorsk, the largest percentage of lead was found in the aboveground organs of sunflower $(0.9 \%)$ and in the aerial organs of lawn grasses, the zinc content was equal to $0.9 \%$.

It was established that in the rhizosphere of planted sunflower plants and a mixture of lawn grasses, the content of heavy metals steadily decreased over 3 months.

Thus, sunflower plants and lawn grasses had high accumulation activity and accumulated a significant amount of heavy metals in their organs. Determination of the content of heavy metals in the soil showed a significant removal of heavy metals from the soil, which indicates a high degree of phytoextraction of heavy metals by the studied plant species.

\section{References}

1. M. Tasekeyev, Promyshlennost' Kazakhstana, 5 (26), 59-63 (2004)

2. L.C. Boluspayeva, M.C. Panin, Sibirskyi ecologicheskyi zhurnal, 6, 803-810 (2012)

3. N.Y. Shkolnik, I.B. Alekseeva-Popova, Rastenia v extremalnyh usloviyah mineralnogo pitania, 176 (Nauka, 1983)

4. M.N. Prasad, Fiziologiia rastenii, 50 (5), 764-780 (2003)

5. W.Wenzel, D. Adriano, D. Salt, R. Smith, Agronomy Monograph, 37, 508 (2000)

6. E. Grill, S. Luffler, E-L. Winnacker, Proc. Nat. Acad. Sci. USA, 86, 6838-6842 (1989)

7. J.W. Huang, S.D. Cunningham, New Phytol, 134, 335-342 (1996)

8. Y.M. Li, R. Chaney, E. Brewer, R. Roserberg, J.S. Angle, A. Baker, R. Reeves, J. Nelkin, Plant and Soil, 249, 107-115 (2003)

9. M.R. Broadly, P.J. White, J.P. Hammond, I. Zelko, A. Lux, New Phytologyst, 173, 677-702 (2007)

10. M.G. Palmergen, S. Clemens, L.E. Williams, U. Kramer, S. Borg, J.K. Schjorring, D. Sanders, Trends Plant Science, 13, 464-73 (2008)

11. R.R. Brooks, Plants that hyperaccumulate heavy metals, 53 (CAB International, Wallingford, UK, 1998)

12. R.L. Chaney, Y.M. Li, J.A. Scott, Improving metal hyperaccumulator wild plants to 
develop commercial phytoextraction systems: Approaches and Progress, 37 (New York, 1998)

13. B. H. Robinson, G. Banuelos, H. M. Conesa, M. W. H. Evangelou, and R. Schulin, Critical Reviews in Plant Sciences, 28(4), 240-266 (2009)

14. H. M. Conesa, M. W. H. Evangelou, B. H. Robinson, Rr. Schulin, The Scientific World Journal Volume, 173829 (2012)

15. B. Kos, H. Grčman, D. Leštan, Plant Soil Environ, 49, 548-553 (2003)

16. E. Lesage, E. Meers, P. Vervaeke, S. Lamsal, M. Hopgood, F.M. Tack, Int J Phytoremediation, 7 (2), 143-152 (2005)

17. Standartnaia operatcionnaia protcedura. LMN/SOP-06. Digestatciia tverdykh prob dlia opredeleniia tiazhelykh metallov v plameni (2002)

18. Standartnaia operatcionnaia protcedura. LMN/SOP-08. Rabochii protcess Analyst 300 Perkin Elmer (v plameni) (2001)

19. G. Agoramoorthy, F.A.Chen, M.J. Hsu, Environmental pollution, 155, 320-326 (2008) 